\title{
Hekimlerce Sıklıkla Göz Ardı Edilen Kafa Travmalarında Meydana Gelen Geçici Bilinç Kaybı Süresinin Adli Raporun Sonucunu Nasıl Etkilediğinin Önemi
}

On the Importance of How Forensic Report's Decision is Affected by The Duration of Temporary Loss of Consciousness Occured in Head Injuries often Ignored by Physicians

\author{
Rıza Yılmaz, Samet Kıyak, Emin Domaç
}

Bülent Ecevit Üniversitesi Tip Fakültesi Adli Tip Anabilim Dal, Zonguldak

Türk Ceza Kanununda tanımlanan yaralanma suçlarının Adli Tıp açısından değerlendirilmesinde kullanılan kriterlerden birisi de 'basit bir tıbbi müdahale ile giderilebilir ya da giderilemez' olduğudur. Türk Ceza Kanununda tanımlanan yaralanma suçlarının Adli Tıp açısından değerlendirilmesinde basit bir tıbbi müdahale ile giderilebilecek ölçüde hafif yaralanma, TCK’nın 86 . maddesinin 2. fikrasında yer verilmiş olup bu terim ceza itibarı ile en hafif yaralanma grubunu ifade etmek için kullanılmışıtır. Hangi travmatik değişimlerin hafif derecede yaralanmalar içinde yer aldığı Adalet Bakanlığı Adli Tıp Kurumu Türk Ceza Kanununda tanımlanan yaralama suçlarının Adli Tıp açısından değerlendirme klavuzunda vücut bölgelerine göre ayrı ayrı listelenmiştir.

Kafa, vücuttaki yerleşim yeri itibarıla travmaya son derece açıktır. Araç içi-dışı trafik kazaları, yüksekten düşme, iş kazaları, darp, senkop vb. nedenlerle kafa travmaları çok sık görülmektedir.

Adli tıp pratiğinde geçici süre ile oluşan bilinç kayıpları oldukça sık görülmekte ise de hekimler bulguları tıbbi belgelere geçirirken geçici olan bu durumu göz ardı edilebilmektedirler. Geçici bilinç kaybını içeren yaralanmalarda, basit bir tıbbi müdahale ile giderilebilecek ölçüde hafif yaralanma olup olmadığına karar vermek için ne kadar süre bilinç kaybının devam ettiğine bakılmaktadır. 5 dakikadan fazla süren geçici bilinç kayıplarında yaralanma ağırlı̆̆ı "basit tıbbi müdahale ile giderilemeyecek" ölçüde bir yaralanmaya dönmektedir. Böyle bir yaralanmanın cezası ise "basit tıbbi müdahale ile giderilebilecek" ölçüde yaralanmaya göre daha fazla olmaktadır.

Kafa travmaları nedeniyle meydana gelen bilinç kaybı süresi değerlendirilirken kişinin ifadesine ek olarak travma nedeniyle oluşan ve muayenede tespit edilebilecek örneğin occipital bölgede hematom varlığı önem arz etmektedir. Bu nedenle kişiye ilk müdahaleyi yapan hekimlerin ve sağllk çalışanlarının hastada bilinç kaybı olup olmadığının ve bilinç kaybı oluştuysa ne kadar süre devam ettiğinin kaydını dikkatli bir şekilde tutması gerekmektedir. Çünkü bilinç kaybının süresinin, düzenlenen adli raporun sonucunu etkilediğine dikkatçekmek istiyoruz. 